interest, which was referred to a special committee appointed by the recent International Congress of Anthropological Sciences held in London in August last. The committee is international in its composition, Great Britain being represented by Capt. T. A. Joyce of the British Museum. The matter, however, is not to be allowed to rest there so far as Great Britain is concerned; and it is announced in the February issue of Man that the British Film Institute has established a Scientific Research Panel of its Advisory Council, of which Prof. J. L. Myres will act as chairman, to collect information as to the extent to which the cinematograph has been used in scientific work, details of methods and difficulties in technique, and particulars of films of scientific interest which have not been put into circulation through the ordinary commercial channels. The Panel will welcome information on any of these points; communications should be addressed to the Secretary, British Film Institute, 4 Great Russell Street, London, W.1.

\section{City and Guilds (Engineering) College, London}

In speaking, at the jubilee celebration of the City and Guilds (Engineering) College, Prof. H. E. Armstrong directed special attention to the origin of the Imperial College, tracing this and the general development of scientific activity at South Kensington mainly back to the late Lord Playfair, in particular to his appointment at the Museum of Practical Geology, the home of the Geological Survey, about 1843. South Kensington, he believes, is still without any memorial of the great 'little' man. Discussing the history of the Royal College of Chemistry, established in Oxford Street in 1845, now the Royal College of Science, Prof. Armstrong said that the funds were chiefly obtained from the farming community, owing to the enthusiasm aroused by Liebig in his tour throughout agricultural England in 184243. When the Royal College of Science was opened, its rural promoters had looked forward to the development of the school in the interests of agriculture. Man may propose but professors dispose : nothing was further from Hofmann's genius. Agricultural chemistry, Prof. Armstrong said, is not taught in England in a way in the least comparable with that in which engineering has been taught in the Guilds Colleges. He ventured to express the hope that, by the time the College of Chemistry celebrated its centenary, it will have learnt what its original purpose was and will seek to fulfil this. By that time perhaps the world will have recognised that no other subject is so worthy of chief attention as is agriculture.

SPEAKING of his work at the Central, after referring to the importance attached both there and at the Finsbury College to engineering as a necessary subject in the chemist's course, Prof. Armstrong said of the engineer: "I made no attempt to teach him chemistry : that I soon found to be impossible. I tried to teach him through simple acts of chemical inquiry, to experiment with a purpose; to observe accurately: above all to describe his work in lucid English: to take notes, in short, the hardest task of all. My schoolmastering was not popular with many, at the time. In after years I have had my full reward, as not a few have told me that my insistence on their learning to help themselves has been of special value to them". $\mathrm{He}$ ended by saying : "At this, perhaps the most critical and solemn moment of my life, in the interests of our national engineering efficiency, I would plead for the recovery of the original spirit and a reconstitution of the College as a separate entity."

\section{Sir Alfred Ewing and Seismometry}

DR. C. DAvison writes : "During the five years (1878-83) that Ewing spent in Japan, like other English teachers in Tokyo he was infected by the enthusiasm of Prof. John Milne, and became one of the first members, and afterwards a vice-president, of the Seismological Society of Japan founded by Milne in 1880. At one of the early meetings of the Society in that year, Ewing described his seismograph for horizontal motion, in which he preceded RebeurPaschwitz in devising a horizontal pendulum with two fixed supports. In 1881 , he followed with an account of a seismometer for vertical motion, this, with the preceding, forming the well-known instrument made by the Cambridge Instrument Co., Ltd. In the follow. ing year, he devised his duplex pendulum seismometer. The horizontal pendulum was erected in the Engineering Laboratory of the University of Tokyo in November 1880, and, at several later meetings of the Seismological Society, he exhibited the diagrams obtained with it. The interest aroused by these early accurate records of the movements of the ground during an earthquake can be readily imagined. Shortly before he left Japan, Ewing wrote his great memoir on 'Earthquake Measurement', in which he described the various forms of known seismographs and their underlying principles (Tokyo Univ. Sci. Dept. Mems., No. 9; 1883). Soon after this, his active interest in seismometry seems to have ceased, for, after his return to Great Britain, he made only one new contribution, that on seismometric measurements of the vibrations of the Tay Bridge during the passing of railway trains (Roy. Soc. Proc., $44,394-402$; 1888). In these experiments made with a duplex pendulum seismometer, he showed that the greatest lateral and longitudinal movements of the bridge were about $\frac{1}{20}$ in. and $\frac{1}{40}$ in. respectively."

\section{Research Laboratory at the National Gallery}

Towards the end of 1934, the Trustees of the National Gallery approved a scheme for the establishment of a laboratory to undertake the physical examination of pictures by means of X-rays, ultraviolet and infra-red radiations, and by micrographic methods. They also appointed a committee, consisting of Sir Henry Lyons, Sir William Bragg, and Dr. H. J. Plenderleith, to act as an advisory body, should need arise : the laboratory is in charge of Mr. F. I. G. Rawlins. A considerable amount of the plant has already been installed, and work has begun with photomicrographic investigations, and to some extent with ultra-violet light. At the present rate of progress 
it is expected that the laboratory will be fully equipped by the end of April. The X-ray apparatus will contain several novel features. In addition, a number of ancillary researches are being initiated, including the microscopical examination of woods used for panels : it is hoped that this inquiry will produce valuable data for making the description of works in future editions of the catalogue more exact, as well as being a help in the question of attribution.

\section{Large Sunspot Group}

A MODERATELy large sunspot group which formed on February 5 has attracted, for its size, an undue amount of notice in the daily Press. The group occupies about 800 millionths of the sun's hemisphere, and a spot of these dimensions will be no uncommon occurrence during the next six or seven years, as the sunspot cycle passes through its maximum in 1938. Actually, a larger group, occupying 1000 millionths of the sun's hemisphere, has already appeared since the last minimum in 1933. This group had its central meridian passage on April 21.9, 1934 (see the Observatory for February 1935, where an account of 1934 sunspot activities will be found). The present spot is, however, not without interest. No spot was detected on a photograph exposed at Greenwich on February 5 at $10^{\mathrm{h}}$, but at $11^{\mathrm{h}}$ a spectroscopic disturbance was seen in the spectrohelioscope, which seems to have been the genesis of the actual spot. On account of eloud, no photoheliogram was taken on February 6, and the spot appeared fully developed on February 7. The spot's latitude is $14^{\circ} \mathrm{S}$., and it was born west of the central meridian. Its central meridian passage - if it survives - will take place on March 14 next. The spot is of such a size that it could just be seen by the naked eye if it was on the central meridian. Near the limb, where the spot appears foreshortened, a spot of this size would be invisible. It is interesting to note that the number of naked eye sunspots per annum follows the ordinary sunspot curve very closely, and that the 11-year cycle could well have been discovered by an observer provided only with a smoked glass-and a good climate.

\section{Natural and Artificial Clouds}

IN his Friday evening discourse at the Royal Institution on February 8, Sir Gilbert Walker discussed natural and artificial clouds. Apart from cumulus clouds of various types, the causes of the geometrical patterns that are to be seen in the sky must be sought in the behaviour of layers of fluid which are made unstable either by heating them from below or cooling them from above. It has been known for fifteen years that a stationary liquid when unstable develops a polygonal pattern, and that an unstable liquid flowing down a trough forms pairs of vortices rotating in opposite directions, with their axes parallel to the direction of flow, or of shear. Sir Gilbert's pupils have carried these investigations further, and A. Graham used a wind tunnel formed with a heated iron plate as lower surface; its upper surface was a cool glass strip
$8 \mathrm{ft}$. long and $9 \mathrm{in}$. wide, a third of an inch above the iron plate. When pulled by a motor, this gave variable rates of shear in the air. The former explanation of clouds occurring in long rolls or in a rectangular pattern as caused by Helmholtz waves was shown to be unsatisfactory; and it was verified that while a rapid shear due to motion exceeding one inch a second produces longitudinal cells, one less than a fifth of that rate leads to transverse cells, and an intermediate rate to a rectangular pattern. Various types of longitudinal clouds were diseussed, and Sir Gilbert withdrew his former explanation of spirals in these clouds as due to stream lines, showing that there are normally two equidistant spirals like those in a twistdrill, and that these appear to be the two component vortices intertwined. Photographs of clouds were used to demonstrate the formation of a number of patterns of clouds at different heights; and an account was given of the explanation suggested by A. Graham of the paradox that, in the laboratory, liquid rises in the axis of a cell while in air there is descent there. Attention was also directed to the existence of clouds due to instability or the sun; and to the use of clouds of longitudinal and rectangular patterns for long. distance gliding under the name of 'cloud-streets'.

\section{Structure of the Universe}

Speaking to the Durham University Philosophical Society on February 1 at Armstrong College, Nowcastle-upon-Tyne, Dr. Herbert Dingle, assistant professor of astrophysics at the Imperial College of Science and Technology, gave a historical account of the development of our ideas of the structure of the universe. Defining the 'universe' as the whole of physical existence, he pointed out that this apparently general subject demands a treatment which is in many respects unique. The idea of infinity became general with the Renaissance, and this seemed to place the conception of the whole universe beyond the power of the finite mind, until Newton restored the possibility with his implicit concept of universal law which was everywhere applicable. There have been two criticisms of this; a valid objection, that this extension of locally derived law may be incorrect; and an invalid one, based on our imperfect knowledge of atomic processes, which ignores the fact that the laws of a whole can be arrived at without combining the laws of elementary parts. Towards the end of last century, it was argued that the Newtonian law of gravitation was inconsistent with an infinite extension of uniformly distributed matter, of how. ever low a density. Relativity theory, however, made such homogeneity acceptable. The Einstein, de Sitter and expanding universes are widely known nowadays, but Dr. Dingle made it clear that there is nothing esoteric about such theories, and that their underlying principles might have been expected from recent observations even if they had not been discovered when they were. It was stated also that there is no objection to belief in an infinite space, if one is willing to admit that in Einstein's space-time it may be quite beyond physical exploration. 